\title{
1. National sovereignty over natural resources: Environmental challenges and sustainable development
}

\author{
Virginie Barral
}

\section{INTRODUCTION}

As Max Huber, in the famous Island of Palmas case, captured perfectly, the nature of the enduring relationship between a polity organized as a State and its territory, including the resources located therein, is one of exclusive jurisdiction. ${ }^{1}$ This vision of sovereignty grants the State exclusive powers over the territory both as an object and as a spatial entity. An independent polity organized as a State hence both 'owns' the territory (dominium) and 'controls' the space (imperium). ${ }^{2}$ Territorial control and ownership, including over resources, are thus an intimate expression of a State's independence as it is an essential attribute of sovereignty.

It is thus little surprise that soon after decolonization, newly independent States affirmed their permanent sovereignty over natural resources (permanent sovereignty) as a means to claim back what they 'owned' (ie natural resources located within their territory) from the foreign corporations that were exploiting them. ${ }^{3}$ Control over resources thus ensured that independence was not just an empty shell but a concrete attribute which would pave the way to economic development. Permanent sovereignty became an instrument for the transformation of existing international economic relations towards the establishment of a New International Economic Order (NIEO) and the recognition of a right to development centered on national sovereignty, fairness and wealth redistribution from the North to the South. ${ }^{4}$ In this sense, permanent sovereignty protects the freedom of the State to choose its own path, regarding the exploration, exploitation and conservation of its natural resources.

This state of affairs, however, masks an inherent tension between the organization of the international society of States on the basis of territorial sovereignty and the interconnected and interdependent nature of the resources of the biosphere, which do

\footnotetext{
1 See Island of Palmas Case (Netherlands v USA) (1928) 2 RIAA 829, at 838.

2 Pierre-Marie Dupuy and Yann Kerbrat, Droit International Public (12th ed., Dalloz, 2014) at 88.

3 See Franz Xaver Perrez, "The Relationship between "Permanent Sovereignty" and the Obligation Not to Cause Transboundary Environmental Damage' (1996) 26 Environmental Law 1187 , at 1190 .

4 Eg 'Declaration on the Establishment of a New International Economic Order', UNGA Res 3201 (1 May 1974), preamble.
} 


\section{Research handbook on international law and natural resources}

not respect artificial territorial delimitations. ${ }^{5}$ In addition, most environmental problems, including resource depletion, today not only transcend national boundaries, they take on a global character. Indeed, the management of tropical forests, for example, whose exploitation and conservation typically falls under the national sovereignty of the State where they are located, directly affects biodiversity and the climate system environmental challenges with characteristically worldwide consequences. ${ }^{6}$

With the growing realization of these ecological interdependencies, the international community of States, alongside and almost concomitantly with the development of the NIEO and its armored conception of sovereignty, started developing principles and standards of environmental protection, including for the conservation of natural resources and the protection of wildlife. Beyond early examples of nature conservation regimes at sectoral or regional levels, the diffusion of general principles of resource protection took on a global dimension in the 1970s and particularly with the 1972 Stockholm Conference on the Human Environment. The Stockholm Declaration calls for safeguarding the natural resources of the Earth for present and future generations ${ }^{7}$ and highlights man's special responsibility to safeguard and wisely manage the heritage of wildlife and its habitat. ${ }^{8}$ The international community's newly emerged concern for the conservation of the resources of the Earth as humanity's home, beyond any national territorial delimitation, is also saliently echoed in the principles of the World Charter for Nature of 1982, which requests that all areas of the Earth be subject to principles of conservation. ${ }^{9}$

A conflict thus emerged between the principle of national sovereignty over natural resources and the idea that each State is master in its own house, on the one hand, and the evolving general principles of resource protection aiming to constrain State behavior regarding natural resources located within their territory, on the other hand. This is a conflict between national sovereignty and survival in an interdependent world. ${ }^{10}$ Whether this conflict can be resolved, and how, poses important questions for the traditional understanding of the notion of sovereignty: have developments in the environmental field led to a renewed conception of sovereignty?

This chapter sheds light on these issues, firstly by exploring briefly how the reorganization of emerging and consolidating international rules and principles of environmental protection around the 'matrix' of sustainable development may allow moving beyond a purely conflictual relationship between national sovereignty and

5 Michael Bowman, 'Environmental Protection and the Concept of Common Concern of Mankind' in Malgosia Fitzmaurice et al. (eds), Research Handbook on International Environmental Law (Edward Elgar Publishing, 2010) 494. See also Chapter 8 in this volume.

6 See Chapter 8 in this volume.

7 'Declaration of the United Nations Conference on the Human Environment' (1972) UN Doc A/CONF.48/14/Rev.1 (Stockholm Declaration), Principle 2.

8 Stockholm Declaration, Principle 4. See also Principles 3 and 5. See Chapter 10 in this volume.

9 UNGA Res 37/7 (28 October 1982), Principle 3. See also Principles 1 and 2.

10 Philippe Sands and Jacqueline Peel, Principles of International Environmental Law (3rd ed., Cambridge University Press, 2012) at 12. 
resource preservation towards one based on mutual interest. ${ }^{11}$ It then reflects on how growing environmental interdependencies and the corresponding rise of new or redefined legal concepts and categories such as common concern, common property, or shared resources, challenge traditional conceptions of sovereignty. Finally, the chapter offers a partial mapping of the widening environmental constraints on national sovereignty over natural resources, ranging from classic situations of transboundary damage; to scenarios where sovereignty constraints flow from a mere international interest in resource protection; through to sovereignty limitations even in the absence of any immediate international interest in resource protection.

\section{FROM ARCADIA TO SUSTAINABLE DEVELOPMENT: RESOURCE 'CONSERVATION' IN THE INTEREST OF NATIONAL SOVEREIGNTY?}

The principle of permanent sovereignty over natural resources, and the freedom endowed to the States to exploit such resources located on their territory as they see fit, may seem irreconcilable with a general duty of nature preservation which restricts the State's right to exploit national resources. The evolution of both environmental law and the law of development at the turn of the twenty-first century, however, has opened the door to a renewed relationship between national sovereignty and resource protection.

Grassroots and deep ecology movements, which significantly contributed to bringing environmental awareness to the fore of the international agenda in the 1960s, were quite notably inspired by 'Arcadian' conceptions of ecology. ${ }^{12}$ Arcadian ecologists are wary of the destructive power of industrialization and advocate a return to a more harmonious relationship with nature. ${ }^{13}$ At the core of Arcadian ecology is nature preservation for its own sake and its own value. Preservationists thus favor an eco-centric form of environmentalism. In contrast, conservationists adopt a much more anthropocentric approach to environmental protection. ${ }^{14}$ If nature is to be protected, it is for the benefit of humans. In that sense, conservationists favor a clearly utilitarian vision of ecology, arguing for the wise use of nature to allow for economic development. In other words, conservationists advocate a sustainable approach to natural resources use. ${ }^{15}$

However, the international environmental movement never embraced a fully preservationist approach to nature protection. It is instead rooted in conservationist and

11 Pierre-Marie Dupuy, 'Où en est le Droit International de l'Environnement à la Fin du Siècle?' (1997) 101 Revue Générale de Droit International Public 873, at 886.

12 Robert Falkner, 'The Rise of Global Environmental Responsibility in World Politics' in Antje Vetterlein and Hannes Hansen-Magnusson (eds), Responsibility in World Politics (Cambridge University Press, forthcoming).

13 Ibid.

14 Ibid.

15 Ibid. On the distinction between preservation and conservation, see also Rosemary Rayfuse, 'Biological Resources' in Daniel Bodansky, Jutta Brunnée and Ellen Hey (eds), Oxford Handbook of International Environmental Law (Oxford University Press, 2007) 363, at 371. 


\section{Research handbook on international law and natural resources}

managerial approaches to environmental stewardship, placing humans' well-being at the center of nature protection concerns. With the growing consciousness of environmental interdependencies and the need to provide global answers to tackle global problems such as ozone depletion, global warming, or the loss of biodiversity, this anthropocentric approach to nature protection was further deepened in a pledge from the industrialized North to get the developing South on board. The link between environmental protection and economic development, already apparent in Stockholm in 1972, culminated in the consecration of the concept of sustainable development at the Rio Conference on Environment and Development in 1992. ${ }^{16}$ This paradigmatic principle aims to cater both for the needs of the present (and hence allow the South to pursue economic development) as well as of future generations. ${ }^{17}$ From that perspective, the environment must be protected and natural resources conserved in a way that will allow future generations to meet their own environmental and developmental needs. Development that is sustainable is thus development that uses environmental protection as a means to ensure long-term economic and social (ie human) development.

Arguably, since the 1992 Rio Conference, modern international environmental law has been reorganized around sustainable development and traditional principles of environmental protection have thus been reinterpreted in this new light. Conceptions of nature conservation have now been largely overtaken by the principle of sustainable use of natural resources, the emphasis being on the capacity to use and exploit natural resources, so long as it is at a rate that does not lead to their long-term decline. ${ }^{18}$ By incorporating development needs into the nature preservation agenda, this shift of emphasis undeniably works some way towards accommodating national sovereignty and resource protection principles. The sustainable utilization of resources indeed promotes long-term and healthy economic development, the very object that the principle of permanent sovereignty over natural resources aims to pursue.

At the same time that the environmental movement integrated economic concerns into its agenda, the South's perception of permanent sovereignty was facing the challenge of an evolving concept of development. The South's demands for the establishment of a NIEO and the recognition of a right to development faced strong northern opposition and ultimately failed to transform international economic relations along these lines. ${ }^{19}$ Instead, the North-South dialogue refocused around the concept of sustainable development as the new overarching definition of economic development reflecting an acceptable compromise. This, in turn, paved the way for a renewed conception of permanent sovereignty in line with the objectives of sustainable development. Indeed, the radical conception of permanent sovereignty adopted by the

16 It is a prominent feature of the United Nations Conference on Environment and Development (UNCED), also known as the Earth Summit, and of its 'Rio Declaration on Environment and Development' (1992) UN Doc A/CONF.151/26.

17 See the definition in Gro Brundtland et al., Our Common Future (World Commission on Environment and Development, 1987) at 51.

18 See Convention on Biological Diversity (adopted 5 June 1992, entered into force 29 December 1993) 1760 UNTS 382, Article 2.

19 See Francesco Francioni, 'Equity in International Law' in Rudiger Wolfrum (ed), Max Planck Encyclopedia of Public International Law (Oxford University Press, 2013) para 24. 
Charter of Economic Rights and Duties of States and the Declaration for a NIEO, never quite took hold. It is instead the earlier General Assembly Resolution 1803 of 1962 that gathered consensus. Accordingly, the 'right of peoples and nations to permanent sovereignty over their natural wealth and resources must be exercised in the interest of their national development and of the well-being of the people of the State concerned'. ${ }^{20}$ Crucially, the resolution acknowledges a strong link between economic development and the well-being of the people.

However, it is also now generally accepted that people's well-being is dependent on the quality of the environment in which they live. In fact, the international community accepts that people's well-being will only be ensured if the State adopts a path of sustainable development which integrates environmental concerns and protects natural resources from depletion to ensure their sustainable use. From this standpoint, the evolution of the conception of development from economic growth to sustainable development may well mean that the principle of permanent sovereignty over natural resources today includes a duty of environmental protection, ${ }^{21}$ as only then can permanent sovereignty be exercised in the interest of development and of the well-being of the people of the State as specified in Resolution 1803. Resource protection, or at least sustainable use, would thus be an integral element of the exercise of national sovereignty. Accordingly, permanent sovereignty over natural resources and resource protection may have found a mutual interest in aiming to achieve sustainable development.

This, however, does not exclude underlying tensions and conflicts. Indeed, even if, at the broad theoretical level, the principles of national sovereignty and nature protection can be reconciled, in practical terms, the law of natural resources remains in a process of evolution. Emerging rules and notions, with sometimes sovereigntyaccommodating overtones, sometimes more overtly conflictual ones, are, in this process, constantly in tension, pulling the law in various directions in search of a renewed conception of national sovereignty. The development of new or redefined concepts and legal categories better fitted to today's international reality of environmental interdependencies thus challenges the traditional understanding of national sovereignty.

20 Ibid., para 1. Some arbitral decisions have seen in this a principle of customary international law: eg, Texaco Overseas Petroleum Company and California Asiatic Oil Company $v$ Government of Libya (1977) 53 International Law Reports 389.

21 On the meaning and implications of sustainable development, see Virginie Barral, 'Sustainable Development in International Law: Nature and Operation of an Evolutive Legal Norm' (2012) 23 European Journal of International Law 377; and Virginie Barral, Le Développement Durable en Droit International: Incidences Juridiques d'une Norme Évolutive (Bruylant, 2015). On whether permanent sovereignty includes duties for States, see Nico Schrijver, Sovereignty over Natural Resources: Balancing Rights and Duties (Cambridge University Press, 1997) especially Chapter 9 and at 391-392. 


\section{INTERDEPENDENCIES AND CHALLENGES TO SOVEREIGNTY}

If most of the Earth is divided into portions of territories allocated to States purporting to exercise their sovereignty therein, classic international law has long recognized limits to this configuration. Indeed, there are still portions of the Earth that have not been appropriated, that are hence beyond national jurisdiction, and whose regimes have instead been devised by international law. Two such regimes inherently challenge the traditional notion of sovereignty. Common spaces, including the high seas, may be exploited by States individually but cannot be appropriated to the exclusive sovereignty of any one State. ${ }^{22}$ Other areas, however, such as the deep seabed ${ }^{23}$ and outer space, have been further internationalized, and individual States may not exploit their resources for their own benefit as these are seen as the common heritage of mankind. In both contexts, the limits placed on sovereignty arise out of the common interest of States in a resource beyond domestic jurisdiction. But States may also have a common interest in resources located within the confines of domestic jurisdiction. This is the case where a resource is shared between two or more States, or where mankind shares a common concern in the impact and exercise of national sovereignty over resources such as biodiversity or the atmosphere. This section will first explore the relationship between the notions of sovereignty and those of common property and common heritage of mankind. It will then investigate the extent to which the legal characterization of shared resources and of common concern of mankind challenges the exercise of State sovereignty or leads to a renewed conception of it.

\subsection{Sovereignty and Internationalized Regimes: Common Property and Common Heritage}

Common spaces beyond national jurisdiction, most notably the high seas, are governed by a regime of common property. ${ }^{24}$ According to this regime, common spaces are insusceptible of appropriation, although the (biological) resources they contain may be appropriated by individual States. In other words, even though States may exploit the natural resources located in the common spaces, they cannot exercise their exclusive jurisdiction therein. Common property thus reflects the common interest of all States in the exploitation of these resources, thereby justifying a regime of open access. Such open access is, however, now being increasingly regulated by a number of international, regional or bilateral fisheries or resource protection conventions. ${ }^{25} \mathrm{~A}$ common interest in exploitation indeed necessarily leads to a common interest in conservation of resources for the benefit of all, as recognized by the International Court of Justice (ICJ)

22 See Patricia Birnie, Alan Boyle and Catherine Redgwell, International Law and the Environment (3rd ed., Oxford University Press, 2009) at 195; and Chapter 18 in this volume.

23 See Chapter 19 in this volume.

24 Birnie, Boyle and Redgwell (n 22), at 194. Other areas include outer space and arguably Antarctica. On the latter, see Chapter 21 in this volume.

25 See Chapter 9 in this volume. 
in the Fisheries Jurisdiction Case. ${ }^{26}$ If left unregulated, the resources of the high seas would soon become depleted to the detriment of all. ${ }^{27}$ In other words, States have come to realize that the long-term exploitation of the seas' living resources will only be ensured through their sustainable use. Ultimately, the common property regime thus places a dual limit on State sovereignty: it subtracts the common space from the exclusive jurisdiction of the State and it subjects resources to exploitation restrictions.

The common heritage of mankind regime takes a step further in limiting sovereignty as it not only internationalizes the space, but also the ownership of resources. In other words, not only is the space not susceptible of territorial appropriation, but neither are the resources. Their exploitation must instead be carried out in the interest of mankind. Admittedly, the effective operation of this radically innovative legal concept has so far been confined to very limited categories of resources: the non-living resources of the deep seabed and, to a lesser extent, those of the Moon. ${ }^{28}$ The regime of the deep seabed undoubtedly currently represents the most advanced form of internationalization as exploitation of the resources of this area and equitable sharing of the benefits are under the control of the International Seabed Authority, itself acting for the benefit of mankind whose interests it represents.

Beyond debates over the practical effectiveness of this original legal category, at the theoretical level, it most certainly challenges the traditional structure of the international society composed of sovereign States. Indeed, exploitation and management of common heritage resources are not in the interest of the international society of States, nor even of the international community. Rather, they are for the benefit of mankind. The concept of common heritage thus goes beyond statehood and transcends the State as the central subject of international law to envisage mankind as a legal entity. Mankind is, for its part, trans-temporal in that it encompasses, past, present and, crucially, future generations. ${ }^{29}$ The exploitation of resources belonging to the common heritage of mankind may thus be seen as the management of resources held in trust for future generations. ${ }^{30}$ The personification of mankind and the idea of trusteeship that accompanies it make appealing legal concepts for international environmental law, ${ }^{31} \mathrm{a}$ discipline in search of innovative legal solutions to address challenging problems that cannot otherwise be solved solely through classic legal mechanisms. If the deep seabed

26 Fisheries Jurisdiction Case (United Kingdom v Iceland) (Merits) [1974] ICJ Reports 3, para 72 .

27 As famously expressed by Garrett Hardin, 'The Tragedy of the Commons' (1968) 162 Science 1243 .

28 See, respectively, UNCLOS Article 136 and Agreement Governing the Activities of States on the Moon and Other Celestial Bodies (adopted 5 December 1979, entered into force 11 July 1984) 1363 UNTS 3, Article 4.

29 Dupuy and Kerbrat (n 2), at 852.

30 See generally Edith Brown-Weiss, In Fairness to Future Generations: International Law, Common Patrimony and Intergenerational Equity (Innovation in International Law) (Transnational Publishing, 1989); see also Peter Sand, 'Principle 27: Cooperation in a Spirit of Global Partnership' in Jorge Viñuales (ed.), The Rio Declaration on Environment and Development. A Commentary (Oxford University Press, 2015) 617, at 623-629.

31 Dupuy and Kerbrat (n 2), at 859. 
regime has thus far not been replicated, ${ }^{32}$ there is a growing tendency to see in the natural environment and its component parts an international public good being held in trust for future generations. ${ }^{33}$ Should the concept of humanity or trust regimes be developed further in the environmental field, natural resources located under domestic jurisdiction could well end up being immunized from the classic operation of the principle of national sovereignty.

\subsection{Sovereignty and Shared Resources}

Natural resources such as migratory birds or fish, wild animals, river and lake ecosystems, forests or mountain ranges do not neatly fit within artificial territorial boundaries and often straddle over two or more sovereign States, raising issues of control powers allocation. Adjustments to national sovereignty are, in such circumstances, in order, and international law offers examples if not of shared sovereignty proper, at least of joint management regimes. The 1970s saw an attempt at the development of a regime of shared natural resources under the auspices of the UN Environment Programme (UNEP), which received a lukewarm response from States due to controversies notably surrounding the use and meaning of the term 'shared resources'. ${ }^{34}$ These led to the discontinuance of related topics at the International Law Commission (ILC) and the removal of references to such terminology in the codification of the law of international watercourses. ${ }^{35}$

The rules contained in UNEP's document, however, were far from displacing the notion of sovereignty altogether and referred to duties of transboundary cooperation, equitable utilization, diligence, information and consultation when a State plans to use the shared resource in a way that might affect the other riparian States. Crucially, despite controversies surrounding UNEP's guidelines, all these principles are now increasingly recognized as reflecting customary international law. In fact, the particular situation of shared or transboundary resources has been judicially acknowledged as far

32 For a discussion of common heritage in relation to marine genetic resources in areas beyond national jurisdiction, see Chapter 20 in this volume.

33 Such an approach can be seen in the Convention for the Protection of the World Cultural and Natural Heritage (adopted 16 November 1972, entered into force 17 December 1975) 1977 UNTS 151 (WHC); the 2003 African Convention on the Conservation of Nature and Natural Resources (revised) (adopted 1 July 2003, not yet in force), Article 4; the Convention on International Trade in Endangered Species (adopted 3 March 1973, entered into force 1 July 1975) 993 UNTS 243 (CITES), preamble; the Bonn Convention on the Conservation of Migratory Species of Wild Animals (adopted 23 June 1979, entered into force 1 November 1983) 1651 UNTS 356 (Bonn Convention), preamble; the United Nations Framework Convention on Climate Change (adopted 9 May 1992, entered into force 21 March 1994) 1771 UNTS 107 (UNFCCC), Article 3.1; and the Convention on the Protection of Underwater Cultural Heritage (adopted 2 November 2001, entered into force 2 January 2009) 2562 UNTS 3.

34 Some States had expressed a preference for the terminology of transboundary resources.

35 The topic of Shared Natural Resources (Oil and Gas) in particular was discontinued at the ILC and for a removal of references to the concept see UNEP Principles on Conservation and Harmonious Utilization of Natural Resources Shared by Two or More States (1978) 17 International Legal Materials 1094, UN Doc IG/12/2, para 15. On watercourses, see Chapter 15 in this volume. 
back as 1929 when the Permanent Court of International Justice, in the River Oder case, referred to the 'community of interest' among an international river's riparian States. ${ }^{36}$ Equitable and reasonable use of shared resources is now accepted as a central customary principle of the law of international watercourses. It finds judicial reflection in the decision of the International Court of Justice (ICJ) in the Gabč́kovo-Nagymaros Project case where the court sees in it a 'basic right' ${ }^{37}$ Equitable and reasonable use also features, along with the cooperation, diligence, notification and consultation duties mentioned, among an increasing range of conventional joint management regimes of shared resources, including international rivers and lakes, wetlands, mountain chains or cultural heritage sites. ${ }^{38}$ Such principles also find reflection in the ILC 2008 Draft Articles on the Law of Transboundary Aquifers. ${ }^{39}$ More recently, in the Pulp Mills case, the ICJ has considered that 'the procedural obligations of informing, notifying and negotiating [...] are all the more vital when a shared resource is at issue, as in the case of the River Uruguay, which can only be protected through close and continuous co-operation between the riparian States' ${ }^{40}$ Crucially the ICJ also imparts a 'greener' meaning to the principle of equitable and reasonable utilization, that should allow for sustainable development which takes account of both the conservation of the river environment and its economic development. ${ }^{41}$

Sustainable development thus appears to have successfully colored the interpretation of the principle of equitable and reasonable use, which now incorporates environmental protection concerns. ${ }^{42}$ The gap between equitable utilization and sustainable use thus seems to be narrowing in favor of the latter, since utilization of a shared resource will only be equitable and reasonable, it seems, if it is sustainable. These mainly procedural obligations are admittedly a long way from displacing the central principle of national sovereignty, yet they do formulate sovereignty constraints - or at least require adjustments to the traditional understanding of sovereignty, as international law today seems to acknowledge that resource protection considerations must be fully integrated within resource use plans.

\subsection{Sovereignty and Common Environmental Concerns}

Yet another innovative legal category requiring adjustments to sovereignty has emerged in response to growing environmental interdependence: the common concern of mankind. Its emergence is the result of a double phenomenon. It was prompted, on the one hand, by the increasingly suspicious attitude of the international community, or at least part of it, vis-à-vis the notion of common heritage, which presupposes significant

36 Case Relating to the Territorial Jurisdiction of the International Commission of the River Oder (1929) PCIJ Reports Series A No 23, at 27.

37 Case Concerning the Gabčíkovo-Nagymaros Project (Hungary/Slovakia) (Judgment) [1997] ICJ Reports 7, para 78.

38 Eg Bowman (n 5), at 498-500.

39 (2008) UN GAOR, 63rd Session Supp No 10, UN Doc A/63/10.

40 Case Concerning Pulp Mills on the River Uruguay (Argentina $v$ Uruguay) (Judgment)

[2010] ICJ Reports 14, para 81.

41 Pulp Mills, para 75.

42 Pulp Mills, para 177. See further Barral (2012) (n 21), at 397. 


\section{Research handbook on international law and natural resources}

transfers and redistribution of sovereignty in favor of humanity. But, it was also facilitated by a renewed international context: the paradigm shift towards sustainable development. The 1992 Rio Conference, by setting this new objective for the international community, acknowledged the latter's global environmental responsibility. The Earth Summit acknowledged both the existence of global environmental concerns and the global demand for such concerns to be adequately addressed. The atmosphere came to be seen as a global unity irrespective of territorial boundaries and its climate-change-induced deterioration a common concern of mankind. ${ }^{43}$ Equally, despite their location within the confines of domestic jurisdictions, the international community's realization that the benefits of biological resources accrue to humanity as a whole led to the recognition of biodiversity's conservation as a common concern to humankind. And so a new concept challenging sovereignty was born.

The fact that it is climate change and the conservation of biodiversity that are recognized as common concerns, rather than the atmosphere or biodiversity per se, has particular implications: it is not a spatial entity or a resource that is the subject of common concern but rather environmental processes and the responses they require. Hence, unlike for common heritage resources or those of the global commons, common concern does not seek to establish common ownership or management. ${ }^{44}$ In that sense, it preserves States' territorial sovereignty. State sovereignty is not, however, left completely intact. Recognition of an issue as a common concern of mankind indeed limits the State's freedom of action as it 'does not fall solely within the domestic jurisdiction of States, owing to its global importance and consequences for all'. ${ }^{45}$ Thus the State's freedom of action may well be limited concerning resources wholly located within their territory, even in the absence of transboundary damage to another State's rights, so long as their conservation is of concern to all. Significantly, the reference to mankind rather than the international community of States furthers the conceptual shift already started by the notion of common heritage. For Stec, it 'implies values that are above and beyond the calculated interests of states' and 'its long-term view, bridging generations also implicitly runs longer than the actual term of sovereignty of a typical form of government. Thus, "common concern" marks a transition from a community of self-interested and autonomous states with absolute territorial sovereignty to a mixed global community with restraints on sovereignty' ${ }^{46}$

At a more practical level, the concept of common concern has two direct legal consequences. Firstly, if an issue is recognized as of common concern, then any legal obligation aimed at addressing this issue will be an obligation owed erga omnes, ${ }^{47}$

43 UNFCCC, preamble recital 1.

44 ILC, Second Report on the Protection of the Atmosphere, Special Rapporteur Murase (2015) UN Doc A/CN.4/681, at 22.

45 Ibid., at 23. See also Stephen Stec, 'Humanitarian Limits to Sovereignty: Common Concern and Common Heritage Approaches to Natural Resources and the Environment' (2010) 12 International Community Law Review 361, at 384.

46 Ibid, at 368 .

47 Or, erga omnes partes, if the recognition of common concern is based on a treaty that does not have universal membership. 
since all States will have an interest in its respect. ${ }^{48}$ Secondly, it will legitimize and even require States' cooperation, perhaps as of necessity, to address the concern since what is at the heart of the notion is the collective responsibility to act. ${ }^{49}$ It thus implies a legal duty of cooperation and of collective action. Put slightly differently, the protection of resources of global significance is in the general interest of mankind, which places a responsibility on States to cooperate for their sustainable development. ${ }^{50}$ Yet, as the concept of common concern leaves the 'ownership' of resources untouched, and not transferred either to the international community or to humanity, it is through the prism of States' sovereign actions in the general interest that their protection and sustainable development may be effected. For Francioni, the concept of common concern is nevertheless transformative of the normative perspective on sovereignty since,

it is no longer seen as absolute power and control over the physical space subject to national jurisdiction but is analyzed through the lens of its functional relationship to the general interest of the world community to respect and protect environmental values. ${ }^{51}$

From this perspective not only do environmental measures gain in legitimacy as they are the outcome of 'democratic-majoritarian decision-making of the people with regard to the use of natural resources'52 but 'the implementation of international environmental law becomes part of a reasonable exercise of sovereignty for the attainment of a common good'. ${ }^{53}$ Obviously such a perception of sovereignty functional to the general interest in environmental protection and resource conservation presupposes a conscientious State that respects democratic processes, or a sufficiently well-informed democratic base. Even in this scenario, the necessity of inter-temporality remains at odds with the notion of the sovereign State, whose life may be quite short and that of its government even shorter. ${ }^{54}$ Eventually, despite its formal preservation of national

48 See Jutta Brunnée, 'Common Areas, Common Heritage and Common Concern' in Oxford Handbook of International Environmental Law (n 15) 551, at 566; Dinah Shelton, 'Common Concern of Humanity' (2009) 1 Iustum Aequum Salutare 33, at 39. Though this has its own limitations in view of both the ill-suited nature of State responsibility in the environmental field and international law's difficulties in recognizing the possibility of an actio popularis, see ILC, Second Report on the Protection of the Atmosphere (n 44), at 24.

49 See ILC, Second Report on the Protection of the Atmosphere (n 44), at 23, citing Duncan French, 'Common Concern, Common Heritage and Other Global(-ising) Concepts: Rhetorical Devices, Legal Principles or a Fundamental Challenge?' in Michael Bowman et al. (eds), Research Handbook on Biodiversity and Law (Edward Elgar, 2016).

50 Birnie, Boyle and Redgwell (n 22), at 130. French, in addition, argues that common concern endows the international community with a legal interest in the domestic affairs of an individual State and in particular in those domestic issues that prevent a State from achieving sustainable development. See Duncan French, 'A Reappraisal of Sovereignty in the Light of Global Environmental Concerns' (2001) 21 Legal Studies 376, at 393.

51 Francesco Francioni, 'The Private Sector and the Challenge of Implementation', in Pierre-Marie Dupuy and Jorge Viñuales (eds), Harnessing Foreign Investments to Promote Environmental Protection: Incentives and Safeguards (Cambridge University Press, 2013) at 30.

52 Ibid., at 32.

53 Ibid.

54 See Stec (n 45), at 381. 


\section{Research handbook on international law and natural resources}

sovereignty the trans-temporal dimension of the concept of common concern, through its designation of mankind as the entity 'concerned', may well in time transcend State sovereignty. ${ }^{55}$

Admittedly, the sovereign State is not on its last breath yet, and in the meantime, it can be safely concluded that even if the emergence or reorientation of the legal concepts and categories explored are not wholly displacing national sovereignty, they are at least adjusting its meaning and perception. A core thread running through notions of common property, common heritage, shared resources, or common concern is no doubt that of the commonality of interest in the resources which such notions aim to regulate and in their conservation with a view to their sustainable use, sometimes even in the interest of future generations. As such, commonality of interest and transtemporality, in and of themselves challenge national sovereignty by subtracting the resources concerned from the State's domaine réservé. Beyond such vast and innovative conceptual categories, sovereignty is further constrained by an increasing range of specific environmental legal standards.

\section{THE RISE OF ENVIRONMENTAL STANDARDS AND SOVEREIGNTY CONSTRAINTS}

If the current structure of the international legal system is premised upon the fundamental principle of sovereign equality and the correlative exclusive territorial jurisdiction which flows from State sovereignty, this same international system has long recognized that such national sovereignty can be, at least voluntarily, fettered. Indeed, as recognized by the arbitral tribunal in the Lac Lanoux case, if territorial sovereignty plays the part of a presumption, it must nevertheless bend before all international obligations, whatever their origin. ${ }^{56}$ Thus, irrespective of the conceptual umbrella under which they are developed - be it common property, common heritage, common concern or shared resources - sovereignty remains increasingly limited by the environmental standards with which States voluntarily comply, or perhaps out of necessity in view of the urgency of the threat posed.

This section will map the range of environmental standards that constrain State sovereignty, be it on the basis of the protection of other States' rights, because of the existence of an international interest in resource protection, or even in the absence of any such immediate international interest. Incidentally, environmental limitations on sovereignty may no longer emanate from exclusively international standards: the absence or weakness of international standards may prompt certain States to apply their own more stringent environmental regulations extra-territorially. While international law discourages the use of extra-territorial unilateral measures, ${ }^{57}$ it does not specifically prohibit it. ${ }^{58}$ There have been examples of such attempts in the environmental field,

55 Ibid, 389.

56 See Lake Lanoux Arbitration (France v Spain) (1957) 12 RIAA 281, at 301.

57 Rio Declaration, Principle 12.

58 The Case of the SS Lotus (France v Turkey) (Judgment) (7 September 1927) PCIJ Reports Series A No 10, at 19-20. 
such as the protective actions of the United States that led to the famous Bering Sea fur seal arbitration. ${ }^{59}$ Such attempts unsurprisingly lead to international disputes which the environmentally minded State has often lost. However, according to Sands, the Dispute Settlement Body of the World Trade Organization has recently adopted a more sympathetic approach to natural resources conservation concerns, even through the adoption of domestic measures applied extra-territorially. ${ }^{60}$ Should the international community fail to adopt sufficiently effective international standards of resource protection, especially as far as shared or common resources are concerned, instances of restrictions of national sovereignty through the extra-territorial application of domestic environmental legislation may increase. This would have the effect of gradually restricting the residual area of freedom from interference of other States.

\subsection{Constraints on Sovereignty for Activities Involving Transboundary Damage and Beyond}

A core international environmental standard constraining States' sovereignty over natural resources flows directly from the central principle of sovereign equality. The obligation not to cause damage to the environment of other States derives from the duty to respect the territorial integrity of other States, an expression of their sovereignty. This has its origin in the principles sic utere tuo ut alienum non laedas and of good neighborliness. Early jurisprudential expressions of this rule are found in the Corfu Channel case, where the ICJ noted that a State has an 'obligation not to allow knowingly its territory to be used for acts contrary to the rights of other States' ${ }^{61}$ while the Trail Smelter and Lac Lanoux arbitrations underlined its specifically environmental dimension. ${ }^{62}$ In the Trail Smelter case, in particular, the Tribunal stated that

no State has the right to use or permit the use of territory in such a manner as to cause injury by fumes in or to the territory or the properties therein, when the case is of serious consequence and the injury is established by clear and convincing evidence. ${ }^{63}$

Essentially, this principle, also known as the 'no harm rule', translates the concern that the way in which a State exercises sovereignty over its natural resources - how it will

59 (United States $v$ Canada) 28 RIAA 263. See also more recently in terms of application of extra-territorial measures: United States - Restriction on the Import of Tuna (3 September 1991) DS/21/R, BISD 39S/155 (unadopted) and (16 June 1994) WT/DS29/R and Fisheries Jurisdiction Case (Spain v Canada) (Judgment) [1998] ICJ Reports 432.

60 See Sands and Peel (n 10), at 193. See also United States - Import Prohibition of Certain Shrimp and Shrimp Products (12 October 1998) WT/DS58/AB/R, para 133. This point is however debated: eg, Robert Howse, 'The Appellate Body Rulings in the Shrimp/Turtle Case: A New Legal Baseline for the Trade and Environment Debate' (2002) 27 Columbia Journal International Environmental Law 489 at 510. See also Chapter 3 in this volume.

61 Corfu Channel (United Kingdom v Albania) (Judgment) (1949) ICJ Reports 4, at 22.

62 Trail Smelter (United States v Canada) (16 April 1939 and 11 March 1941) 3 RIAA 1905, 1965 and Lake Lanoux.

63 Trail Smelter; Lake Lanoux. Although admittedly the Trail Smelter Arbitration insisted more on the duty of reparation once the injury was caused rather than on the duty to prevent such harm to occur. 
extract, transform and exploit them - may have consequences for the environment of other States. It thus places restraints on the use of sovereignty over natural resources to avoid such harm. The fact that the no harm rule places a limit on the permanent sovereignty principle is clearly expressed in the Stockholm and Rio Declarations where these two principles are inextricably linked. ${ }^{64}$ The obligation not to cause damage to the environment of other States or to areas beyond national jurisdiction thus acts as a balance on the right to freely exploit natural resources and thereby constrains sovereignty. The customary status of this principle is today unquestioned. ${ }^{65}$

Technically, the obligation not to cause damage to the environment of other States translates into a duty of prevention, itself requiring due diligence on the part of the State exercising its sovereignty over natural resources. ${ }^{66}$ The principle of prevention that the 'no harm rule' entails, as far as it can be distinguished from the latter, also reflects a customary rule. ${ }^{67}$ The no harm rule poses not an absolute, but a relative obligation on States - an obligation to deploy the means necessary to avoid harm without requiring that they achieve this result. It is thus known as an obligation of means or conduct: what is expected of the State is "not only the adoption of appropriate rules and measures, but also a certain level of vigilance in their enforcement and the exercise of administrative control applicable to public and private operators, such as the monitoring of activities undertaken by such operators [...]'. ${ }^{68}$

If the constraint on sovereignty derived by the application of the no harm rule flows itself from the principle of territorial integrity, arguably, as formulated in the Stockholm and Rio Declarations and as understood by international courts and tribunals, it has moved beyond this application as an extension of the principle of sovereignty. The general obligation of the State is indeed not only to refrain from causing harm to the environment of other States, but also to areas beyond national jurisdiction. ${ }^{69}$ DuvicPaoli and Viñuales note that this

changes the perspective of the obligation: the State is not only required to prevent transboundary harm in order to respect the sovereignty of other States but is obliged to protect the environment as such, including those areas such as the global commons which have no connection to State sovereignty. ${ }^{70}$

64 See Principles 21 and 2 respectively. The drafting of Rio Principle 2 is almost identical to that of Stockholm Principle 21, which only omits the reference to "and developmental."

65 Legality of the Threat or Use of Nuclear Weapons Advisory Opinion (1996) ICJ Reports 241, para 29; Gabčíkovo-Nagymaros, para 5; Arbitration Regarding the Iron Rhine ('Ijzeren Rijn') Railway between the Kingdom of Belgium and the Kingdom of the Netherlands (Award) (24 May 2005), 27 RIAA 35, para 222.

66 See Article 3 of the ILC Draft Articles on Prevention of Transboundary Harm from Hazardous Activities (2001) 2 Yearbook of the International Law Commission.

67 Iron Rhine Railway, para 59; Pulp Mills, para 101.

68 Pulp Mills, para 197.

69 See Stockholm Declaration, Principle 21; Rio Declaration, Principle 2; Legality of the Threat or Use of Nuclear Weapons, para 29.

70 Leslie-Anne Duvic-Paoli and Jorge Viñuales, 'Principle 2. Prevention' in Viñuales (n 30) 107 , at 117 . 
This shift in emphasis from sovereignty to the environment per se favors a non-spatial or a-territorial approach to environmental protection ${ }^{71}$ and thus opens the way to an extension of the application of the principle to the State's own environment. In other words, some see in the principle of prevention an obligation on States to protect their own environment from degradation ${ }^{72}$ and there are indeed some treaty examples of such domestic constraints on sovereignty. ${ }^{73}$ Duvic-Paoli and Viñuales seem to suggest that it may even have acquired customary status. ${ }^{74}$ Whether it has already crystallized or not, the customary principle according to which States are obligated to protect the environment even in the absence of any transboundary harm is in the process of development. This makes sense in so far as, in view of environmental interdependencies, the international community shares an interest in environmental protection by all, within their own jurisdiction. Domestic environmental degradation may indeed have global consequences. In these circumstances, constraints on sovereignty may flow from an international interest in resource protection. Either way, the due diligence (ie non-absolute) nature of the principle of prevention aptly expresses the requirements of sustainable development since it requires a balance between permanent sovereignty and the duty not to cause harm, hence a balance between economic development and environmental protection. In fact, the increasing recognition of an obligation for States to strive to achieve sustainable development may well work in favor of the recognition of a domestic obligation of due diligence towards the environment since sustainable development requires the integration of economic, environmental and social considerations. In this sense, an obligation to prevent harm to the domestic environment would indeed be compatible with the requirement that the exercise of permanent sovereignty be in the interest of the well-being of the people, including their environmental and social well-being, and thus promoting sustainable development.

\subsection{Constraints on Sovereignty in Cases of International Interest in Resource Protection}

\subsubsection{Sustainable use, sustainable development and commonality of interest}

Sustainable use is understood to require resource management which yields the greatest sustainable benefit to present generations while maintaining its potential to meet the needs and aspirations of future generations. ${ }^{75}$ This objective thus implies an intergenerational perspective and the adoption of holistic and integrated management

71 Ibid at 117-118. Though, see contra André Nollkaemper, 'Sovereignty and Environmental Justice in International Law' in Jonas Ebbesson and Phoebe Okowa (eds), Environmental Law and Justice in Context (Cambridge University Press, 2009) 253, at 256-257.

72 See also Sands and Peel (n 10), at 201.

73 See, for example, United Nations Convention on the Law of the Sea (adopted 10 December 1982, entered into force 16 November 1994) 1833 UNTS 3 (UNCLOS), Article 192 or the Convention on the Law of Non-Navigational Uses of International Watercourses (adopted 21 May 1997, entered into force 17 August 2014) UN Doc A/51/869, Article 20.

74 See Duvic-Paoli and Viñuales (n 70), at 119.

75 See Robert Munro and Johan Lammers, Environmental Protection and Sustainable Development: Legal Principles and Recommendations Adopted by the Experts Group on 
strategies based on the precautionary and ecosystem approach 'that account for scientific, economic, social, and political uncertainties and that recognize the importance of both consumptive and non-consumptive uses' ${ }^{76}$ The principle of sustainable use is a prolongation of the concepts of resource protection, resource preservation and resource conservation, ${ }^{77}$ as well as of those of wise use, rational use or optimum sustainable yield - all of which feature in a range of international instruments concerning biological resources, or wild fauna and flora protection predating the Rio Conference. By the time of the Rio Conference, however, 'sustainable use had been universally accepted as the basis upon which all living resources should be managed'. ${ }^{78}$

Sustainable use is closely related to, and an essential measure for, the achievement of the objective of sustainable development and, as such, constitutes an acceptable limitation on State sovereignty as it in fact allows reconciliation between permanent sovereignty and resources protection. Indeed, according to this principle, the use of natural resources, rather than being prohibited, must be exercised in a manner that ensures its long-term use and the resource's capacity for regeneration. As such, it works in favor of a continued exploitation of the resource and allows for the attainment of the objective of permanent sovereignty: ensuring the well-being of the people of the State. By guarding against resource depletion, it preserves and furthers the economic, social and potentially cultural well-being which the people accrue from the exploitation of the resource, who conversely would suffer from its depletion and extinction. By integrating the objectives of permanent sovereignty and resource protection, sustainable use thus contributes to achieving a development that is sustainable.

As a principle of resource management, sustainable use has thus generalized into an international environmental standard capable of constraining the State's sovereignty to exploit resources located within its own territory. The legitimacy of such a constraint stems from the commonality of interests that States or humankind share in the conservation of such resources, even in the absence of a transboundary damage to another State. The principle of sustainable use as embedded in the Conservation of Biological Diversity (CBD) is a salient example of domestic limitation of sovereignty for resources located within the jurisdiction of the State, which finds its legitimacy in the common concern that humankind shares in the conservation of biodiversity. Potentially because both the 'concern' and those concerned are more diffuse than in a case of common or shared property over a resource, the formulation of the obligations of sustainable use have a softer character in the CBD regime than in other global regulatory regimes, such as UNCLOS. The strength of the legal commitments to restrict national sovereignty also increases in a regional or local context, when the common interest of States is more immediately felt.

Environmental Law of the World Commission on Environment and Development (Graham and Trotman/Martinus Nijhoff, 1986) at 9.

76 See Rayfuse (n 15), at 373.

77 On the distinction between these notions, see Rayfuse (n 15), at 370-371.

78 Sam Johnston, 'Sustainability, Biodiversity and International Law' in Catherine Redgwell and Michael Bowman (eds), International Law and the Conservation of Biological Diversity (Kluwer Law International, 1996) 51. 


\subsubsection{Sustainable use and global regulatory regimes}

Under the CBD, the principle of sustainable use, particularly the sustainable use of the components of biodiversity, is at the heart of the convention. ${ }^{79}$ It is defined as

the use of components of biological diversity in a way and at a rate that does not lead to the long-term decline of biological diversity, thereby maintaining its potential to meet the needs and aspirations of present and future generations. ${ }^{80}$

This imposes on States obligations to cooperate; adopt strategies for the conservation and sustainable use of biological resources; identify and monitor important components of biodiversity; establish systems of protected areas for in situ conservation; and complementary measures of ex situ conservation. ${ }^{81}$ CBD Article 10 requires the integration of conservation and sustainable use into national decision-making and the adoption of measures of resource use to avoid adverse impacts on biodiversity. Despite the mandatory language throughout, these are admittedly weak commitments. The Convention does not set a clear and straightforward general obligation to use the components of biodiversity in a sustainable manner, and the provisions are further tempered by qualifications such as 'as far as possible and appropriate' or 'in accordance with [...] [the State's] particular conditions and capabilities'. Sustainable use thus struggles to constrain State sovereignty in a strict way. The balance seems all the more set in favor of State sovereignty since CBD Article 3 reiterates Stockholm Principle 21; and CBD Article 15 subjects access to genetic resources to the authorization of the State where these are located. Arguably, however, this bolstering of national sovereignty may ultimately work in favor of resource protection. By laying out the conditions under which access to the exploitation of genetic resources is going to be granted (to other States), the State of origin may well set up a system ensuring their conservation and sustainable use, even if originally in its purely domestic interest. ${ }^{82} \mathrm{In}$ that sense, the subjection of resource access to the principle of national sovereignty empowers the State of origin to design sustainable resource management regimes.

Beyond the universal scope of the Convention, the softness of States' commitments to use components of biodiversity sustainably may well be a consequence of the diffuse nature of the interest that mankind shares in biodiversity and its components. The economic value of biological resources is not always apparent, and, consequently, the immediacy of the benefits that States can derive from them or the necessity of their conservation may be less intensely felt. It remains the case, however, that despite the relative character of the CBD provisions relating to sustainable use, they do not leave national sovereignty completely intact. States are still subject to cooperation obligations and obligations to adopt a range of measures ultimately encouraging sustainable use.

79 CBD, Article 1 Objectives.

80 CBD, Article 2.

81 CBD, Articles 5, 6, 7, 8 and 9, respectively.

82 A system of access and benefit sharing has been further elaborated by the 2010 Nagoya Protocol: see Chapter 11 in this volume. On the link with sustainable use, see Elisa Morgera et al., Unravelling the Nagoya Protocol: A Commentary on the Nagoya Protocol on Access and Benefit-sharing to the Convention on Biological Diversity (Brill/Nijhoff Publishers, 2014) at $48 \mathrm{ff}$. 
Exploitation of biological resources has thus been subtracted from their exclusive jurisdiction, even though such elements might be located within the boundaries of their territory. The wide and generalized acceptance of such constraints has also been acceptable specifically because it has developed under the umbrella of sustainable use. Indeed, contrary to preservationist or intrinsic value philosophies, the principle of sustainable use is essentially value-oriented and anthropocentric in nature. This makes it an acceptable compromise for States to limit their sovereignty as they can see in it, even if sometimes in a diffuse manner, their own interest.

In contrast to the $\mathrm{CBD}$, under the law of the sea it is easier to deduce more constraining sustainable-use obligations. UNCLOS Articles 192 and 193, for example, apply to the marine environment generally, irrespective of questions of jurisdictional delimitations. This means that the duty of States to protect and preserve the marine environment, which qualifies their sovereign right to exploit their natural resources, binds them even within the boundaries of their territorial sea. Because UNCLOS Article 193 balances the obligation to preserve the marine environment with permanent sovereignty, it can be deduced that the obligation on States is really one of sustainable use rather than a general obligation to protect the environment. Indeed, States may exploit their resources, but only while respecting environmental limitations - that is, in a sustainable manner. This can be further deduced from UNCLOS obligations to prevent over-exploitation in the Exclusive Economic Zone (EEZ), ${ }^{83}$ as well as to cooperate to ensure the conservation and optimum utilization of migratory fish stocks in the EEZ ${ }^{84}$ or of the resources of the high seas. ${ }^{85}$ In fact, the International Tribunal for the Law of the Sea in 2015 confirmed that UNCLOS imposed an obligation on States to ensure sustainable management of shared stocks while they occur in their EEZ. 86

\subsubsection{Sustainable use and regional or local regulatory regimes}

Sustainable use obligations are also widespread in regional or local natural resources regulatory regimes where the common or shared interest is more vividly felt by States, with post-UNCED agreements being increasingly premised upon the objective of sustainable use as a basis for constraining State sovereignty domestically. At the regional level, for example, the African Convention on the Conservation of Nature and Natural Resources, in its 2003 revised version, requires States to adopt and implement all measures necessary to achieve the objective of fostering the conservation and sustainable use of natural resources. ${ }^{87}$ Interestingly, the revision was also intended to expand elements related to sustainable development ${ }^{88}$ and the language of sustainable use now replaces that of wise use. Among regional seas conventions, the 2008 Protocol on Integrated Coastal Zone Management of the Mediterranean provides that 'Parties

\footnotetext{
83 UNCLOS, Article 61.2.

84 See UNCLOS, Articles 63 and 64. See also Filleting within the Gulf of St Lawrence Between Canada and France (17 July 1986) 19 RIAA 225, para 50.

85 See UNCLOS, Articles 116 and 119. See also, more generally, Chapter 9 in this volume.

86 See Request for an Advisory Opinion Submitted by the Sub-Regional Fisheries Commission (Advisory Opinion) (2 April 2015) ITLOS Reports 2014, paras 191-192 and 207.

87 See African Convention, Articles 2 and 4.

88 See Birnie, Boyle and Redgwell (n 22), at 656.
} 
shall endeavor to ensure the sustainable use and management of coastal zones in order to preserve the coastal natural habitats, landscapes, natural resources and ecosystems' ${ }^{89}$ In mountain areas, the Carpathian Convention obliges States to 'pursue policies aiming at conservation, sustainable use and restoration of biological and landscape diversity' and to 'take appropriate measures to ensure a high level of protection and sustainable use of natural and semi-natural habitats'. ${ }^{90}$ As far as lakes are concerned, the objective of the 2003 Convention on the Sustainable Management of Lake Tanganyika is to "ensure the protection and conservation of the biological diversity and the sustainable use of the natural resources of Lake Tanganyika and its Basin [...]'. ${ }^{91}$ Significantly, these regimes are unbothered by the lack of primarily transboundary issues. States are subject to these obligations domestically by virtue of the interest they share in the resources at stake.

Sustainable use is also prominent in river systems agreements. ${ }^{92}$ The 1994 Danube River Protection Convention expects the parties to 'strive at achieving the goals of a sustainable and equitable water management, including the conservation, improvement and the rational use of surface waters and ground water in the catchment area as far as possible', ${ }^{93}$ whereas the 2002 Incomati and Maputo River Tripartite Agreement aims to 'promote co-operation among the Parties to ensure the protection and sustainable utilization of the water resources of the Incomati and Maputo watercourses' ${ }^{94}$ It identifies for this purpose sustainable utilization as a key general principle to apply. ${ }^{95}$ Concerns for the protection of ecosystems have thus become more salient in recent river treaty systems and act as a balance to the principle of equitable and reasonable utilization. ${ }^{96}$ In fact, in 2004, the commentary to the ILA Berlin Rules on Water Resources Law noted that sustainability is a 'separate and compelling obligation that [...] conditions the rule of equitable and reasonable use without displacing it' ${ }^{97}$ It may actually be that the principle of sustainable use, as an expression of sustainable development, is slowly replacing that of equitable and reasonable utilization. ${ }^{98}$

89 Article 8. See also the Convention for Cooperation in the Protection and Sustainable Development of the Marine and Coastal Environment of the Northeast Pacific (adopted 18 February 2002, not yet in force), Article 5; and the 2003 Framework Convention for the Protection of the Marine Environment of the Caspian Sea (adopted 4 November 2003, entered into force 12 August 2006) 44 ILM 1, Article 2.

90 Framework Convention on the Protection and Sustainable Development of the Carpathians (adopted 22 May 2003), Article 4.

91 Article 2. See also Protocol for Sustainable Development of the Lake Victoria Basin (adopted 29 November 2003), Article 7.

92 See Chapter 15 in this volume.

93 Article 2.

94 Article 2.

95 See Article 3. See also Framework Agreement on the Sava River Basin (adopted 3 December 2002, entered into force 3 December 2002) Article 11 and Agreement on the Cooperation for the Sustainable Development of the Mekong River Basin (adopted 5 April 1995, entered into force 5 April 1995) 34 ILM 864, Articles 1-3.

96 Eg Malgosia Fitzmaurice, 'The Relationship between the Law of International Watercourses and Sustainable Development' in Bodansky, Brunnée and Hey (n 15), 615.

97 ILA Berlin Rules (2004), at 16.

98 See Pulp Mills, para 177. 


\subsubsection{Sustainable use and customary international law: Concluding remarks}

According to the ILA,

as a matter of common concern, the sustainable use of all natural resources represents an emerging rule of general customary international law, with particular normative precision identifiable with respect to shared and common natural resources. ${ }^{99}$

A recent arbitral decision has also found that 'since the time of Trail Smelter, a series of international conventions, and judicial and arbitral decisions have addressed the need to manage natural resources in a sustainable manner'. ${ }^{100}$ These assertions find support in the provisions relating to sustainable use incorporated in the regimes discussed above. Birnie, Boyle and Redgwell also admit that "the evidence of treaty commitments, coupled with indications of supporting State practice, might be sufficient to crystallize conservation and sustainable use of natural resources into an independent normative standard of international law.' ${ }^{101}$ They warn, however, 'It is clear that States retain substantial discretion in giving effect to the alleged principle, unless specific international action has been agreed' ${ }^{102}$ As reflected in the regimes reviewed above, with some rare exceptions, where the principle of sustainable use constrains State sovereignty, it does so as an objective to be achieved, leaving the State some room for maneuver as to how much effort to put into it. This flexibility, together with the clear anthropocentric nature of the principle, make it for States a more acceptable constraint on sovereignty than a general obligation to protect their own environment. It constitutes in this sense a useful tool to limit national sovereignty, even in the absence of any transboundary damage.

Its appeal, however, has its own boundaries. Firstly, the management of tropical forests, in which humanity's interest is undisputed, is a dire example of the failure of the principle of sustainable use to trump national sovereignty: the 'polarization and sensitivity over sovereignty issues still inhibits the conclusion of a comprehensive global convention despite the accelerating destruction of tropical forests'. ${ }^{103}$ Secondly, where the principle of sustainable use of natural resources constrains the State's sovereignty over resources located within its own territory, this is because the State shares an interest with others in this resource, either as a shared resource or because its conservation constitutes a common concern of mankind. Either way, there is an international or common interest in resource conservation.

992012 Sofia Guiding Statements on the Judicial Elaboration of the 2002 New Delhi Declaration of Principles of International Law Relating to Sustainable Development (2012), para 3.

100 Indus Waters Kishenganga Arbitration (Pakistan v India) (Partial Award) (18 February 2013), para $449<$ http://www.pca-cpa.org> accessed 5 September 2015.

101 Birnie, Boyle and Redgwell (n 22), at 200.

102 Ibid.

103 Ibid, at 695. 


\subsection{Constraints on Sovereignty in the Absence of an Immediate International Interest in Resource Protection}

Unless there is a clear recognition that protection of the global environment is a common concern of humankind, it seems difficult to discern the existence of a general obligation on States to protect their own environment or to exploit their natural resources in a domestic context in a sustainable manner. Yet, there are some international rights or resource protection models that may help shape and conceptualize the contours of such an obligation. The 1999 Protocol on Water and Health to the Helsinki Convention applies to all waters within the territory of a party, including internal and domestic waters. ${ }^{104}$ It thus designs international rules in respect of resources for which States do not have a common interest: they are not shared, nor does their protection constitute a common concern of humankind. Yet, the parties 'shall take all appropriate measures to prevent, control and reduce water-related disease within a framework of integrated water-management systems aimed at sustainable use of water resources, ambient water quality which does not endanger human health, and protection of water ecosystems'. ${ }^{105}$ Hey rightly points out that the Protocol 'distances itself from the classical inter-State paradigm'106 in that its central objective 'is the interest of individuals and groups in society in drinking water of sufficient quality and quantity and water for sanitation'. ${ }^{107}$ Critically, it places the responsibility for protecting that interest on individual States parties within their own territory. ${ }^{108}$ Resource protection must thus be ensured not because of States parties' shared interest in it, but in the interest of the well-being of the people of the State. The focus in this context is on the protection of individual rights. It highlights how human rights law, and its quintessentially anthropocentric character, may well provide an alternative medium for domestic constraints on States' rights to use natural resources domestically when, in the absence of shared international interest, purely ecocentric considerations are unlikely justifications for sovereignty limitation. ${ }^{109}$ States are not selfless, and if they agree to respect human rights it is because ultimately it benefits someone, be it individuals rather than sovereign entities. Human beings are, after all, at the center of concern of human-made law. From this point of view, human rights may well constitute an alternative model for constraining State sovereignty and imposing a general duty on States to conserve and use natural resources sustainably, even absent any purely international element, except for maybe the shared interest in the well-being of humans (humankind?). The right to safe and sufficient drinking water is but one example which would require conservation and sustainable use of such resource that is essential to

\footnotetext{
104 Article 3.

105 Article 4.

106 Ellen Hey, 'Distributive Justice and Procedural Fairness in Global Water Law' in Ebbesson and Okowa (n 71) 351, at 357.

107 Ibid.

108 Ibid.

109 See Chapter 4 in this volume.
} 


\section{Research handbook on international law and natural resources}

human beings. The right to food would provide another, this time impacting on a much broader array of resources. ${ }^{110}$

\section{CONCLUSION}

The growing realization of global interdependencies coupled with the rise of international environmental standards and new legal categories has put the concept of national sovereignty over natural resources under attack. Limitations on national sovereignty thus flow from innovative legal categories such as common heritage, humanity, intergenerational equity or common concern of mankind. Other constraints are derived from the generalization of international rules such as the no harm and prevention principles, as well as the principle of sustainable use. Though unsurprisingly, the more diffuse the commonality of interests or the international element, the weaker the resulting limitation on State powers. Human rights law may offer an alternative model for constraining State sovereignty in relation to the conservation of natural resources even in a purely domestic context. Yet this approach remains premised on anthropocentric considerations. Ultimately, sovereignty limitations grounded in intrinsically ecocentric concerns are as yet unlikely to break ground.

To the contrary, the primarily utilitarian vision of environmental and natural resources protection finds further confirmation in the generalization of the principle of sustainable development and the reorganization of most international environmental law around this paradigmatic 'conceptual matrix'. ${ }^{111}$ If the environment is to be protected, it is for the benefit of the economic and social well-being of individuals, peoples and States. It is under the sustainable development umbrella that sovereignty and resource conservation can be reconciled: there they have found their common and mutual interest. The parameters of such reconciliation, however, have yet to be specified in a number of areas. An example of an issue that would deserve further elucidation is that of the ambiguous relationship between the principle of sustainable development and the principle of equitable use in the field of shared water resources. Is the trend in international law to seek for an accommodation of these two principles, or is the principle of equitable use in fact being subsumed into that of sustainable development, as the ICJ seems to suggest in the Pulp Mills case? ${ }^{112}$ Equally, the precise legal implications of the concept of common concern of humankind remains in need of clarification, in particular as regards its relationship with state responsibility. Could the common concern regime relating to atmospheric resources work towards facilitating the engagement of state responsibility for human-induced climate change?

110 On the right to water and the right to food, see Committee on Economic, Social and Cultural Rights, General Comment 15 (2002) UN Doc E/C.12/2002/11, and General Comment 12 (1999) UN Doc E/C.12/1999/5, respectively.

111 Dupuy (n 11), at 886.

112 See Pulp Mills, para 177. 
Hopefully, the work of the ILC on the topic of the protection of the atmosphere will be able to provide useful guidance in this respect, as well as on the principle of sustainable development itself. ${ }^{113}$

113 See ILC, Second Report on the Protection of the Atmosphere (n 44), at 47. 